\title{
Pain assessment in critically ill patients: an integrative literature review
}

Monitorização da dor na pessoa em situação crítica: uma revisão integrativa da literatura Seguimiento del dolor en pacientes en estado crítico: una revisión integradora de la literatura

Joana Moreira Ferreira Teixeira*; Maria Cândida Durão**

\begin{abstract}
Background: Pain is usually present in critically ill patients, with an impact on their overall health status. For this reason, pain management is essential, involving pain assessment, observation and treatment using appropriate assessment scales/indicators for identifying pain intensity and assessing the effectiveness of the interventions.

Objective: To identify the scales/indicators to be used for assessing pain in critically ill patients.

Methodology: Integrative literature review through the search for published and gray literature in the MEDLINE, CINAHL and the Cochrane Central Register of Controlled Trials databases.

Results: We found 34 documents, and selected 7 final documents for data extraction and analysis.

Conclusion: The BPS, BPAS and CPOT are considered to be the most suitable pain assessment instruments for critically ill patients. The pain indicators found were pupil diameter variation, ventilator asynchrony, restlessness and body movements, facial expressions and vocalizations.
\end{abstract}

Keywords: critically ill patient, pain, monitoring, evaluation, scales, indicators

\section{Resumo}

Contexto: A dor está quase sempre presente na pessoa em situação crítica, tendo esta impacto no estado geral do indivíduo. Por este facto, a gestão da dor torna-se essencial, envolvendo a sua avaliação, monitorização e tratamento, através do uso de escalas e indicadores de monitorização da dor adequados, que permitam identificar a sua intensidade e avaliar a eficácia das intervenções implementadas.

Objetivo: Conhecer as escalas/indicadores a utilizar na monitorização da dor da pessoa em situação crítica.

Metodologia: Revisão integrativa da literatura, realizada através da pesquisa de trabalhos publicados e literatura cinzenta, pesquisa de artigos nas bases de dados MEDLINE, CINAHL e Cochrane Central Register of Controlled Trials.

Resultados: Identificaram-se 34 resultados, dos quais se selecionaram 7 documentos finais para extração e análise.

Conclusão: As escalas BPS, BPAS e CPOT são apontadas como as escalas mais adequadas para avaliação da dor no doente crítico. Os indicadores de dor referidos são a variação do diâmetro pupilar, a assincronia do ventilador, a inquietude e os movimentos do corpo, expressão facial e as vocalizações.

Palavras-chave: doente crítico; dor; monitorização; avaliação; escalas; indicadores

* RN, CUF Cascais Hospital, 2750-663, Cascais, Portugal [joanamf@ hotmail.com]. Contribution to the article: literature search; data collection, analysis and discussion; statistical treatment and assessment; article writing.

Address for correspondence: Rua Fernão Lopes 60 Cobre, 2750-663, Cascais, Portugal.

** MSc., Coordinating Professor, Lisbon School of Nursing, 1600-190, Lisboa, Portugal. Contribution to the article: data analysis and discussion, article writing

\section{Resumen}

Contexto: La persona en estado crítico tiene dolores muy a menudo, y estos provocan un impacto en su estado general. Por ello, la gestión del dolor resulta esencial e implica la evaluación, el seguimiento y el tratamiento del mismo mediante escalas e indicadores de control adecuados que permitan identificar su intensidad y evaluar la eficacia de las intervenciones realizadas.

Objetivo: Conocer las escalas/indicadores que se utilizarán en el seguimiento del dolor de la persona en estado crítico. Metodología: Revisión integradora de la literatura llevada a cabo a través de una búsqueda en la literatura publicada y gris en las bases de datos MEDLINE, CINAHL y Cochrane Central Register of Controlled Trials databases.

Resultados: Se identificaron 34 resultados, de los cuales se seleccionaron 7 documentos finales para extraerlos y analizarlos.

Conclusión: Las escalas BPS, BPAS y CPOT se citan como las escalas más adecuadas para evaluar el dolor en pacientes en estado crítico. Los indicadores de dolor mencionados son la variación del diámetro de la pupila, la asincronía del ventilador, la inquietud y los movimientos corporales, la expresión facial y las vocalizaciones.

Palabras clave: pacientes críticamente enfermos, dolor, seguimiento, evaluación, escalas, indicadores.

Received for publication: 30.03 .16 Accepted for publication: 18.07 .16 


\section{Introduction}

Pain is usually present in critically ill patients (CIPs) and its manifestation is associated both with the underlying disease that motivates their admission to the emergency room (ER) and the intensive care unit (ICU) and the several invasive and non-invasive procedures required. Patients' experience is also aggravated by communication difficulties, fear and anxiety. This has an impact on their overall status and is evidenced by alterations in consciousness, movement, sleep, and endocrine, metabolic, gastrointestinal, and psychological functions (Urden, Stacy, \& Lough, 2008). Since pain management in CIPS can reduce the risk for complications, its assessment and treatment are considered to be a priority.

Pain is a relevant focus of attention in nursing practice, being defined as a subjective experience of suffering with impact on several dimensions of the individual's well-being (Conselho Internacional de Enfermeiros, 2010). Acute pain is usually associated with an pathological event, it is self-limiting and has an important physiological warning function; there is a clear response of the organism to an aggressive agent, which translates into a need for systematic surveillance; it has a sudden onset and is transitory (Howard \& Steinmann, 2011).

CIPs may be conscious and oriented, have consciousness alterations due to sedation or not, and/or communication alterations due to orotracheal intubation or other conditions related to their physio-pathological situation (Nürnberg Damström, Saboonchi, Sackey, \& Björling, 2011). Pain management and control in these patients involves surveillance and observation, which requires the use of pain assessment scales based on pain indicators. These scales allow identifying pain intensity, implementing (dependent or independent) differentiated interventions and assessing their effectiveness. Assessing pain in CIPs is difficult since they usually have consciousness alterations (due to sedation or not) and verbal communication alterations (usually due to presence of orotracheal intubation or continuous non-invasive ventilation). With regard to these patients, nurses can observe the physiological and behavioral indicators of pain (Urden et al., 2008). The scales that use these indicators are called behavioral pain scales and are an important instrument for pain management and assessment in critical care (Urden et al., 2008).
Pain management and control in CIPs involves not only its assessment and observation, but also the implementation of interdependent (pharmacological measures) and independent (non-pharmacological measures) interventions for its treatment (Ferreira et al., 2014; Conselho Internacional de Enfermeiros, 2010). Every inpatient has the right to these interventions, and it is consensual that pain increases the risk of complications and reduces patients' comfort and well-being (Ordem dos Enfermeiros, 2008; Urden et al., 2008). On the other hand, even when there is an effective intervention in this area, there are gaps in some pain management-related areas which are highlighted by some authors, such as the lack of systematic pain assessment/observation (Barreira \& Gomes, 2008; Maria, Sallum, Garcia, \& Sanches, 2010).

The success of a therapeutic strategy oriented towards the person in pain depends on systematic pain assessment and observation, so as to enable nurses to adjust the treatment plan when pain relief is inadequate (Ordem dos Enfermeiros, 2008). Thus, with the purpose of contributing to pain management and control in CIPs, we conducted this integrative literature review to identify the most appropriate scales and indicators to be used in assessing pain among CIPs. The following research question was formulated to achieve the research objective: What pain assessment scales and pain indicators should be used to promote pain management in critically ill patients?

\section{Methodological Procedures of Integrative Review}

The integrative literature review (IRL) was conducted based on the guidelines of the Joanna Briggs Institute for Evidence Based Practice (Joanna Briggs Institute [JBI], 2014), and the research question that guided the search was formulated in PICO format: What pain assessment scales and pain indicators should be used (I) to promote pain management $(\mathrm{O})$ in critically ill patients $(\mathrm{P})$, in which the participants are critically ill patients, the independent variables are pain scales and indicators, and the outcome is pain management, with the purpose of identifying the appropriate scales and indicators to be used in assessing pain in critically ill patients. 
Table 1 describes and justifies the inclusion and exclusion criteria which were defined according to the type of study, participants, intervention (independent variable), results to be achieved and date of publication (JBI, 2014). The language in which the article was written was not used as an exclusion criterion because we accepted documents in all languages, knowing that some could eventually need to be translated some into Portuguese. This was not the case since all the articles obtained through the search were written in English, Spanish and Portuguese.

Table 1

Inclusion and exclusion criteria

\begin{tabular}{lll}
\hline & Inclusion criteria & Justification \\
\hline Participants & $\begin{array}{l}\text { Critically ill patients aged 18 years } \\
\text { or more }\end{array}$ & $\begin{array}{l}\text { There are specific scales for children due to their variability of } \\
\text { behaviors in response to pain (Sarmento et al., 2013). }\end{array}$ \\
\hline $\begin{array}{l}\text { Intervention (Inde- } \\
\text { pendent variable) }\end{array}$ & $\begin{array}{l}\text { Studies that report the use of pain } \\
\text { assessment scales/tools and indica- } \\
\text { tors. }\end{array}$ & $\begin{array}{l}\text { Pain assessment requires adequate scales/instruments to quantify } \\
\text { pain in an individual, assigning a final score based on the observa- } \\
\text { tion of pain indicators (Tomey \& Alligood, 2002). }\end{array}$ \\
\hline Results & $\begin{array}{l}\text { This review considers all docu- } \\
\text { ments that include pain manage- } \\
\text { ment in their results. }\end{array}$ & $\begin{array}{l}\text { According to the Ordem dos Enfermeiros (2008), the nurse is } \\
\text { responsible for implementing independent and interdependent } \\
\text { interventions for pain management and control. }\end{array}$ \\
\hline Documents & $\begin{array}{l}\text { This review considers all types of } \\
\text { available documents, published } \\
\text { or not. }\end{array}$ & $\begin{array}{l}\text { To obtain the best available evidence on the topic under analysis. } \\
\text { Exclusion criteria }\end{array}$ \\
\hline All documents published before 2003 & $\begin{array}{l}\text { Justification } \\
\text { Year in which pain was considered as valuable and important as } \\
\text { Other vital signs concerning the need for systematic surveillance } \\
\text { and documentation (Direção Geral de Saúde, 2003). }\end{array}$ \\
\hline
\end{tabular}

Note: All documents that did not meet the above-mentioned inclusion criteria were excluded.

We conducted the search between 1 and 15 September 2015 with the purpose of finding papers published in the MEDLINE, CINAHL and Cochrane Central Register of Controlled Trials databases. We also searched for unindexed/unpublished papers available in libraries and gray literature. With regard to the database search, we first entered the search terms in natural language, which were formulated based on a few keywords of articles related to the topic under analysis for the identification of the specific descriptors of each database. Subsequently, the specific descriptors of each database found in the previous natural search were included as Major Heading (MH). The following terms were also used: critical patient, pain assessment, pain evaluation, pain control, and pain scales for the search in the abstracts (AB); and acute patient, severe patient, pain instruments, pain relief, and pain level for the search in full text (TX). We adopted the following search strategy: (P) [critically ill patients OR critical illness OR critical patient OR acute patient OR severe patient] AND (I) [pain scales OR pain instruments OR pain measurement OR pain assessment OR pain evaluation OR pain management] AND (O) [pain control OR pain relief OR pain level].
We obtained a total of 34 articles.

We applied the same criteria to search for unindexed/ unpublished papers available in libraries and gray literature, which resulted in the inclusion of one master's dissertation.

\section{Results and Interpretation}

We read all titles and abstracts, with the aim of excluding those which did not meet the inclusion criteria (Table 1). This was followed by a second selection process through full-text reading (outlined in Figure 1). We obtained total of seven documents for data extraction and analysis.

Two reviewers performed this process independently, and the final result was obtained after a consensus meeting.

We extracted and synthesized the data from the final documents using a support form (Table 2), with the purpose of summarizing the documents, identifying their title, author, year, methodological characteristics, objectives, results and conclusions, limitations and future recommendations. 


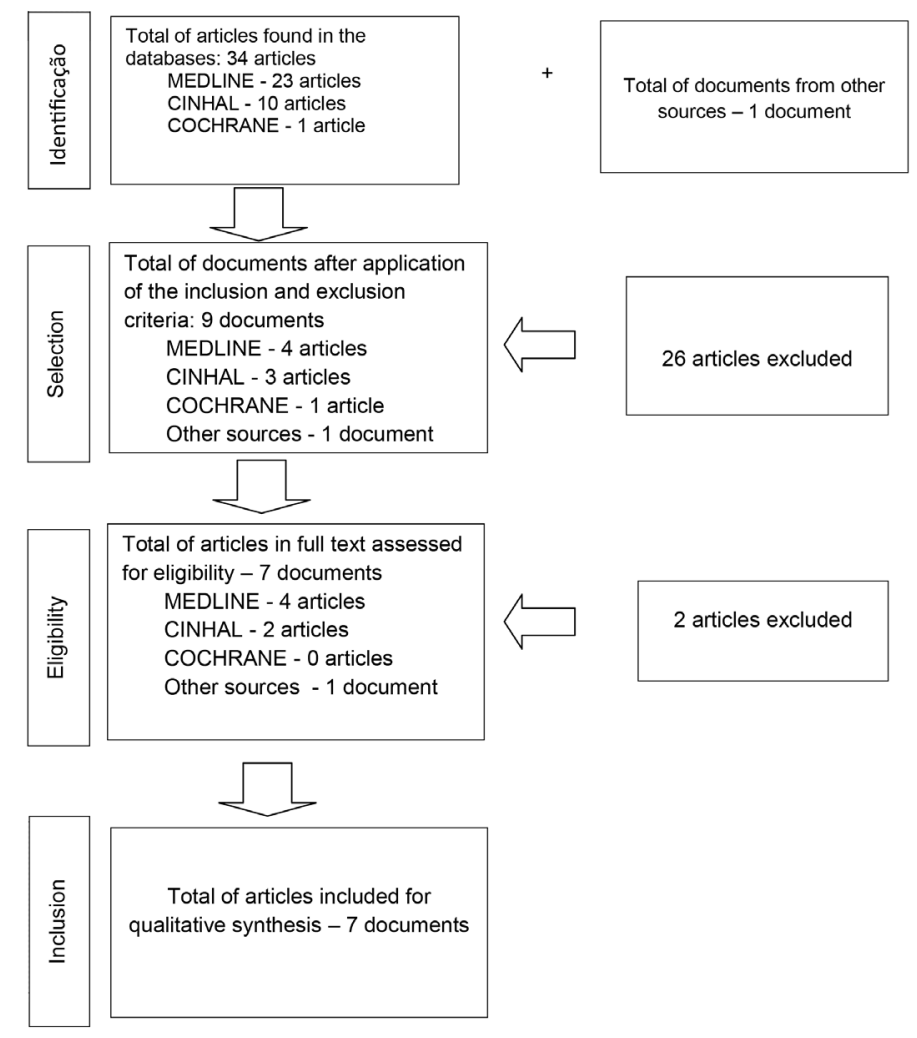

Figure 1.Selection of included studies.

Table 2 shows the final results and the characterization of the documents obtained in the search. The results indicate that the Behavioral Pain Scale (BPS), Behavioral Pain Assessment Scale (BPAS) and the Critical-Care Pain Observation Tool (CPOT) are the most appropriate scales for pain assessment in critically ill patients (Marques, 2009; Paulus et al., 2013). These scales and the Nonverbal Pains Scale (NVPS) had reasonable reliability scores, and the Face, Legs, Activity, Cry, Consolability (FLACC) scale was also considered to have reasonable validity criteria. However, both NVPS and FLACC were considered to have limited usefulness in adults (Odhner, Wegman, Freeland, Steinmtez, \& Ingersoll, 2003). Taking into account these results and the fact that the BPS should only be used in ventilated patients, we consider that pain assessment is hampered in some nonventilated critically ill patients with consciousness and communication alterations, also given the lack of quality indicators for the provision of care to critically ill patients in pain. With regard to pain indicators, the literature mentions the following indicators: pupil diameter variation, increase of 1 point on the
BPS, and ventilator asynchrony (Paulus et al., 2013), restlessness and body movements (Haslam, Dale, Knechtel, \& Rose, 2012), and facial expressions (ArifRahu \& Grap, 2010; Haslam et al., 2012; Odhner et al., 2003). Although Arif-Rahu and Grap (2010) report some inconsistency in the definition of facial expression descriptors, they also mentioned that data obtained through the Facial Action Coding System refer to empirical evidence demonstrating that facial expressions can be accurately used in pain assessment instruments. We should also mention the importance of producing evidence on the effectiveness of nonpharmacological interventions so that they can be used together with pharmacological interventions in order to achieve safer and more cost-effective outcomes (Gélinas, Arbour, Michaud, Robar, \& Côté, 2013); the administration of an analgesic bolus before endotracheal suctioning (Paulus et al., 2013); the importance of pain management, together with sedation and delirium management, giving priority to pain assessment and observation before the use of sedatives and hypnotics; and the need to document pain management interventions so as to ensure the 
continuity of care in this context (Haslam et al., 2012). Systematic pain assessment and treatment reduces the length of mechanical ventilation and hospital stay (Haslam et al., 2012; Marques, 2009; Paulus et al., 2013). The lack of quality assessment of the articles and the lack of a broader search for gray literature are two limitations of this study. Taking into account that pain is always present in critically ill patients, knowledge about the most suitable pain scales and indicators can contribute to improving the quality of evidence-based practice.

Table 2

Characterization of the documents

\begin{tabular}{|c|c|c|c|c|}
\hline $\begin{array}{l}\text { Title/Author/ } \\
\text { Year }\end{array}$ & $\begin{array}{l}\text { Methodological } \\
\text { characteristics }\end{array}$ & Objectives & Results and Conclusions & $\begin{array}{l}\text { Limitations/Recommenda- } \\
\text { tions }\end{array}$ \\
\hline $\begin{array}{l}\text { O fenómeno } \\
\text { da dor numa } \\
\text { unidade de } \\
\text { cuidados } \\
\text { intensivos } \\
\text { (Marques, } \\
\text { 2009) }\end{array}$ & $\begin{array}{l}\text { Master's thesis } \\
\text { - Methodologi- } \\
\text { cal, exploratory } \\
\text { and descriptive } \\
\text { study }\end{array}$ & $\begin{array}{l}\text { To confirm the } \\
\text { validation of } \\
\text { pain assessment } \\
\text { scales to help } \\
\text { improve the } \\
\text { quality of the } \\
\text { care provided } \\
\text { to intensive } \\
\text { care patients. }\end{array}$ & $\begin{array}{l}\text { Pain is a complex, frequent and relevant phenomenon; it } \\
\text { is manifested through physiological and behavioral indica- } \\
\text { tors, translated into instruments that must be used system- } \\
\text { atically so as to detect and assess pain. The Behavioral Pain } \\
\text { Scale (BPS), the Behavioral Pain Assessment Scale (BPAS) } \\
\text { and the Critical Care Pain Observation tool (CPOT) are } \\
\text { adequate scales to assess pain in patients in ICUs. The BPS } \\
\text { and BPAS show significant reliability, validity and sensitivity } \\
\text { to be used in sedated and mechanically ventilated patients. } \\
\text { The study on the incidence and variability of pain shows } \\
\text { that: pain is a frequent phenomenon in ICUs, and it in- } \\
\text { creases significantly during procedures, even in patients } \\
\text { under sedation and analgesia; pain manifestations contrib- } \\
\text { ute to the onset of complications, increase the length of } \\
\text { hospital stay and the number of post-discharge complica- } \\
\text { tions, which requires a more effective pain detection, } \\
\text { assessment and observation. }\end{array}$ & $\begin{array}{l}\text { Limitations: The psycho- } \\
\text { metric properties of the } \\
\text { CPOT were not analyzed } \\
\text { due to lack of time and } \\
\text { unavailability of the profes- } \\
\text { sionals for the application } \\
\text { of } 3 \text { scales. } \\
\text { The process of validation of } \\
\text { the CPOT into Portuguese } \\
\text { is not yet completed. }\end{array}$ \\
\hline
\end{tabular}

Patients report more pain during positioning techniques and/or secretion aspiration. Premedication before pain procedures is not part of nurses' care routine in ICUs. Pain assessments are usually performed during rest. There is a huge variability in pain perception and response to analgesia. Sedatives and delirium hamper pain self-report.

Pain may be inevitable; inadequate Literature management review is not (Skrobik, 2008)
To raise health professionals' awareness for pain assessment and management in intensive care It is important to assess pain first, then sedation, so as to avoid excessive sedation, and, finally, delirium which may be a confounder for pain or insufficient sedation. There is lack of pain assessment and management documentation. Pain assessment and evaluation of the effectiveness and titration of analgesics are recommended. The implementation of protocols should ensure that adequate treatments are provided. The use of paracetamol and nonsteroidal anti-inflammatory drugs (NSAIDs), together with opiates, reduces the need for high doses of the former, although their side effects in CIPs are not well described. Evidence on the benefits of non-pharmacological interventions in ICU patients is scarce.

\begin{tabular}{|c|c|c|c|c|}
\hline $\begin{array}{l}\text { Pupillary re- } \\
\text { flex measure- } \\
\text { ment predicts } \\
\text { insufficient } \\
\text { analgesia } \\
\text { before en- } \\
\text { dotracheal } \\
\text { suctioning } \\
\text { in critically } \\
\text { ill patients } \\
\text { (Paulus et al., } \\
\text { 2013) }\end{array}$ & $\begin{array}{l}\text { Quantitative } \\
\text { study - pro- } \\
\text { spective study, } \\
\text { conducted in } \\
\text { a surgical ICU } \\
\text { of a hospital } \\
\text { in France, with } \\
34 \text { sedated } \\
\text { and mechani- } \\
\text { cally ventilated } \\
\text { patients aged } \\
\text { between } 18 \text { and } \\
85 \text { years, with a } \\
\text { pain score equal } \\
\text { to or higher } \\
\text { than } 3 \text { in the } \\
\text { BPS. }\end{array}$ & $\begin{array}{l}\text { To assess } \\
\text { the pupillary } \\
\text { dilatation reflex } \\
\text { during a tetanic } \\
\text { stimulation to } \\
\text { predict insuffi- } \\
\text { cient analgesia, } \\
\text { before nocicep- } \\
\text { tive stimulation } \\
\text { in an ICU }\end{array}$ & $\begin{array}{l}\text { In sedated patients, the pupil diameter variation can } \\
\text { predict the quality of analgesia. A pupil diameter variation } \\
\text { above } 5 \% \text { after a } 20 \mathrm{~mA} \text { tetanic stimulation is highly indica- } \\
\text { tive of insufficient analgesia during endotracheal suction. } \\
\text { An analgesic bolus should be administrated before endo- } \\
\text { tracheal suctioning. An insufficient analgesia was defined } \\
\text { by an increase of } 1 \text { point on the BPS. The inconsistency of } \\
\text { systematic pain assessment in ICUs justifies the use of low } \\
\text { or high dosages of analgesics or hypnotics with an impact } \\
\text { on patient outcomes. Acute pain can lead to ventilator } \\
\text { asynchrony, increased risk of brain injury and acute respira- } \\
\text { tory distress syndrome (ARDS), discomfort, prolonged me- } \\
\text { chanical ventilation, confusion, increased length of hospital } \\
\text { stay, increased mortality, metabolic changes, and increased } \\
\text { risk of chronic disease. The BPS is a useful tool to assess } \\
\text { and monitor pain in patients who are unable to report pain } \\
\text { intensity, due to sedation or other factors. }\end{array}$ & $\begin{array}{l}\text { Limitations: The pupil } \\
\text { diameter variations, rather } \\
\text { than its absolute value, } \\
\text { were measured, which } \\
\text { can be affected by several } \\
\text { variables (noise, light, high } \\
\text { sedation, other drugs, trau- } \\
\text { matic brain injury (TBI), } \\
\text { among others). } \\
\text { Further studies should be } \\
\text { conducted to validate the } \\
\text { pupil diameter as guide } \\
\text { for the administration of an- } \\
\text { algesia in sedated patients } \\
\text { in ICUs. }\end{array}$ \\
\hline
\end{tabular}




\begin{tabular}{|c|c|c|c|c|}
\hline $\begin{array}{l}\text { Patients and } \\
\text { ICU nurses' } \\
\text { perspectives } \\
\text { of non-phar- } \\
\text { macological } \\
\text { interventions } \\
\text { for pain } \\
\text { management } \\
\text { (Gélinas et } \\
\text { al., 2013) }\end{array}$ & $\begin{array}{l}\text { Descriptive } \\
\text { qualitative } \\
\text { study, through } \\
\text { semi-structured } \\
\text { interviews to six } \\
\text { patients/family } \\
\text { members with } \\
\text { previous experi- } \\
\text { ence of ICU } \\
\text { hospitalization } \\
\text { and ICU nurses. }\end{array}$ & $\begin{array}{l}\text { To describe the } \\
\text { perceptions of } \\
\text { patients/family } \\
\text { members and } \\
\text { nurses about } \\
\text { the usefulness, } \\
\text { relevance and } \\
\text { feasibility of } \\
\text { non-pharmaco- } \\
\text { logical interven- } \\
\text { tions for pain } \\
\text { management in } \\
\text { an ICU. }\end{array}$ & $\begin{array}{l}\text { Of the } 33 \text { non-pharmacological interventions addressed, } \\
\text { the most useful, relevant and reliable ones were music } \\
\text { therapy, distraction, simple massage, and family presence } \\
\text { facilitation. Nurses mostly valued teaching and positioning } \\
\text { interventions, while patients/relatives mostly valued active } \\
\text { listening and reality orientation. } \\
\text { It is recommended that ICU nurses use non-pharmaco- } \\
\text { logical interventions complementary to pharmacological } \\
\text { interventions for pain management. }\end{array}$ & $\begin{array}{l}\text { Limitations: small sample } \\
\text { size. }\end{array}$ \\
\hline $\begin{array}{l}\text { Pain descrip- } \\
\text { tors for } \\
\text { critically } \\
\text { ill patients } \\
\text { unable to } \\
\text { self-report } \\
\text { (Haslam et } \\
\text { al., 2012) }\end{array}$ & $\begin{array}{l}\text { Mixed method, } \\
\text { retrospective }\end{array}$ & $\begin{array}{l}\text { To analyze pain } \\
\text { descriptors/ } \\
\text { indicators used } \\
\text { in two Cana- } \\
\text { dian ICUs to } \\
\text { document pain } \\
\text { presence. }\end{array}$ & $\begin{array}{l}\text { A total of } 679 \text { descriptors were extracted: } 232 \text { behavioral, } 93 \\
\text { physiological and } 117 \text { that indicate pain presence/absence. } \\
\text { The results described analgesia administration without } \\
\text { descriptors of pain presence/absence and analgesic admin- } \\
\text { istration before painful procedures. } \\
\text { Restlessness, grimacing and body movements suggest } \\
\text { presence of pain. } \\
\text { Difficulty in distinguishing behaviors as the result of pain, } \\
\text { agitation or delirium. } \\
\text { Many nurses interpret body movements, tachypnea and } \\
\text { ventilator asynchrony as signs of insufficient sedation and } \\
\text { not as signs of intense pain. Recent studies suggest the } \\
\text { importance of pain assessment together with sedation } \\
\text { and delirium assessment, prioritizing pain assessment and } \\
\text { monitoring before the use of sedatives and hypnotics. } \\
\text { The systematic pain assessment and treatment reduces } \\
\text { the duration of mechanical ventilation and hospital length } \\
\text { of stay. }\end{array}$ & $\begin{array}{l}\text { Limitations: The narratives' } \\
\text { meanings were not ana- } \\
\text { lyzed, which may have led } \\
\text { to different interpretations. } \\
\text { Context and patient severity } \\
\text { can influence the documen- } \\
\text { tation of pain assessment or } \\
\text { lack thereof. } \\
\text { This study only included } \\
\text { two units, which hampered } \\
\text { the generalization of } \\
\text { results. } \\
\text { Recommendations: further } \\
\text { studies should be con- } \\
\text { ducted on the translation of } \\
\text { pain assessment tools. }\end{array}$ \\
\hline
\end{tabular}

Study conducted in a burn and trauma ICU. The FLACC To analyze the scale and NVPS were used in nonverbal ventilated patients. adequacy (valid- A total of 200 assessments were performed to 59 patients. ity and reliabil- The authors found that both the FLACC scale and NVPS ity) of the Adult had reasonable reliability, reasonable criterion validity, Nonverbal Pain especially FLACC; lack of a comparator that confirms that Scale (NVPS) high or low scores express more or less pain in patients; and the Face, the cry and consolability component of the FLACC scale Legs, Activity, had a low scores, which means that it should not be used Cry, Consolabil- in adults; the deletion of these two components, of a total ity (FLACC) of five components, limits the use of this scale in adults; scale to assess although the vital signs component of the NVPS is compapain in nonver- rable to the cry component of the FLACC scale, it cannot bal patients in be deleted because of its impact on the total score; the ICUs. component on physiological parameters (skin characteristics) has the less significant impact on the total score.
Limitations: With limited usefulness concerning the use of these scales in adults. It identifies potentially more appropriate indicators.

Recommendations: further studies should be conducted in which the nursing team is more involved in data collection, patients have a greater variety of diagnoses, and which associate pain assessment with the administration of analgesia to assess the effectiveness of medication. 


\section{Conclusion}

This SLR aimed at identifying the most appropriate scales and indicators to be used for assessing pain in critically ill patients. Results show that the key to pain management is to assess, intervene and reassess after each intervention by identifying indicators such as pupil diameter variation, facial expression, ventilator asynchrony, restlessness and body movements. The BPS, BPAS and CPOT are the most appropriate tools to assess pain in intensive care patients. The BPS is the most widely used scale. However, not all nonverbal patients are ventilated and BPS should only be used in this situation. Since the CPOT can be applied to ventilated and non-ventilated patients, we recommend that future studies should use it in different clinical practice settings. This SLR also points to the need to develop evidence on the efficacy/effectiveness of nonpharmacological pain interventions, which can support their implementation together with analgesia, in order to optimize its effect, with lower doses of drugs, which, consequently, allow for the minimization of side effects and financial costs. In view of the above, it is possible to improve the care provided to critically ill patients in pain and reduce the costs for healthcare institutions, since pain affects patients as a whole, their stability, and treatment effectiveness.

\section{References}

Arif-Rahu, M., \& Grap, M. (2010). Facial expression and pain in the critically ill non-communicative patient: State of science review. Intensive and Critical Care Nursing, 26(6),343-352. doi: 10.1016/j.iccn.2010.08.007

Barreira, A., \& Gomes, O. (2008). Avaliação e registo da dor : Um imperativo em enfermagem. Retrieved from http://www. infiressources.ca/fer/depotdocuments/Avaliacao da dor-O_Gomes-mars2010.pdf

Conselho Internacional de Enfermeiros. (2010). CIPE versão 2: Classificação internacional para a prática de enfermagem. Lisboa, Portugal: Ordem dos Enfermeiros.

Direção-Geral de Saúde. (2003). A dor como $5^{\circ}$ sinal vital: Registo sistemático da intensidade da dor (Circular Normativa $\mathrm{n}^{0}$ 9 CGDG, de 14/06/2013). Retrieved from http://www.myos. com.pt/files/circular5sinalvital.pdf

Ferreira, N., Miranda, C., Leite, A., Revés, L., Serra, I., Fernandes, A. P., \& Freitas, P. T. (2014). Dor e analgesia no doente crítico. Revista Clínica do Hospital Prof. Doutor Fernando Fonseca, 2(2), 17-20. Retrieved from http://repositorio.hff.min-saude. pt/bitstream/10400.10/1383/1/95-213-1-SM.pdf
Gélinas, C., Arbour, C., Michaud, C., Robar, L., \& Côté, J. (2013). Patients and ICU nurses' perspectives of non-pharmacological interventions for pain management. Nursing in Critical Care, 18(6), 307-318. doi: 10.1111/j.1478-5153.2012.00531.x

Haslam, L., Dale, C., Knechtel, L., \& Rose, L. (2012). Pain descriptors for critically ill patients unable to self-report. Journal of Advanced Nursing, 68(5), 1082-1089. doi: 10.1111/j.1365-2648.2011.05813.x

Howard, P., \& Steinmann, R. (2011). Enfermagem de urgência: Da teoria à prática (6a ed.). Loures, Portugal: Lusociência.

Joanna Briggs Institute. (2014). Joanna Briggs Institute reviewers' manual: 2014 edition. Retrieved from http://joannabriggs. org/assets/docs/sumari/reviewersmanual-2014.pdf

Maria, A., Sallum, C., Garcia, D. M., \& Sanches, M. (2010). Dor aguda e crônica: Revisão narrativa da literatura. Acta Paulista de Enfermagem, 25(Esp.), 150-154. doi: 10.1590/S010321002012000800023

Marques, M. (2009). O fenómeno da dor numa unidade de cuidados intensivos (Dissertação de mestrado não publicada). Retrieved from https://repositorio.cespu.pt/ handle/20.500.11816/136

Nürnberg Damström, D., Saboonchi, F., Sackey, P. V., \& Björling, G. (2011). A preliminary validation of the Swedish version of the critical-care pain observation tool in adults. Acta Anaesthesiologica Scandinavica, 55(4), 379-386. doi: 10.1111/j.1399-6576.2010.02376.x

Odhner, M., Wegman, D., Freeland, N., Steinmtez, A., \& Ingersoll, G. (2003). Assessing pain control in nonverbal critically ill adults. Dimensions of Critical Care Nursing, 22(6), 260-267. doi: 10.1097/00003465-200311000-00010

Ordem dos Enfermeiros. (2008). Dor: Guia orientador de boa prática. Retrieved from http://www.ordemenfermeiros.pt/ publicacoes/Documents/cadernosoe-dor.pdf

Paulus, J., Roquilly, A., Beloeil, H., Théraud, J., Asehnoune, K., \& Lejus, C. (2013). Pupillary reflex measurement predicts insufficient analgesia before endotracheal suctioning in critically ill patients. Critical Care, 17(4), R161. doi: 10.1186/ cc12840

Sarmento, P., Marcos, A., Fonseca, C., Marques, M., Lemos, P., \& Vieira, V. (2013). Recomendações para o tratamento da dor aguda pós-operatória em cirurgia ambulatória. Retrieved from http://www.apca.com.pt/documentos/anestesia/ recomendacao_DorAguda.pdf

Skrobik, Y. (2008). Pain may be inevitable; Inadequate management is not. Critical Care, 12(2), 142. doi: 10.1186/ cc6865

Tomey, A. M., \& Alligood, M. R. (2002). Teóricas de enfermageme a sua obra. Lisboa, Portugal: Lusociência.

Urden, L., Stacy, K., \& Lough, M. (2008). Enfermagem de cuidados intensivos ( $5^{\mathrm{a}} \mathrm{ed}$.). Loures, Portugal: Lusodidacta 
